\title{
A REÁLOPCIÓK ELSŐ 40 ÉVE
}

A reálopció-elmélet az elmúlt negyven évben meglátásaival, empirikus bizonyítékaival folyamatosan hozzájárult a stratégiaimenedzsment-kutatásokhoz, legyen szó a piacra lépés időzítéséről és módjáról, a szervezeti forma megválasztásáról, a külföldi működőtőke-befektetésekről, vagy a verseny és együttműködés trade-off vizsgálatokról, ugyanakkor az elmélet megértése, alkalmazása máig is kihívásokkal tarkított nem csak a stratégiai menedzsment területén, de eredeti céldiszciplínája, a beruházási síkon egyaránt. Jelen tanulmány a reálopciók alkalmazási lehetőségét foglalja egy stratégiai keretbe, megkísérelve a kutatásokban és gyakorlati alkalmazásban fellelhető, a generalista modellformálástól távoli, eset jellegű gyakorlatot egy stratégiai logikai ívre felfűzni. A felépített keretrendszer stabilitását, a reálopciók azonosítási, ki-, illetve felépítési, értékelési és hatékony menedzselési folyamatának ismertetését követően egy több mint ezer elemű absztrakt irodalomkutatás eredményeivel igazolja a szerző. A kutatás egyértelműen alátámasztja a stratégiai irány létjogosultságát, valamint olyan jövőbeli irányokat azonosít, mint a reálopciók portfóliószemléletű elemzése, vagy az általános értékelési modell iránti igény.

Kulcsszavak: reálopció-elmélet, beruházás, stratégiai menedzsment

A következőkben a reálopció-elméletet, a reálopciók azonosításának folyamatát, a reálopciók típusait, a reálopciós értékvezérlőket, a reálopció menedzsmentet egy sajátos, stratégiai keretrendszeren keresztül mutatom be. Célom ezzel, hogy rávilágítsak a reálopció-elmélet mint döntéstámogató eszköz gyakorlati alkalmazásának lehetőségeire, annak előnyeire és hátrányaira, a reálopció-elmélet stratégiai keretrendszerbe foglalásának módjára. Azok számára, akik most ismerkednek a reálopció-elmélettel első lépésben az alapvető definíciók, típusok számbavétele következik, rávilágítva a reálopciók jelenlétének felismerhetőségére, valamint a típusok közötti különbségekre. A tanulmányt egy absztrakt irodalomkutatás eredményeivel zárom le, mely a meglévő reálopciós kutatási eredmények számbavételét kísérli meg azon szignifikáns kutatási irányok azonosításának céljával, ahol az elmélet, valamint a gyakorlati alkalmazás elörelépéseket ért el a megjelenése óta eltelt 40 évben, melléktermékként pedig rámutatva azokra a területekre, amelyek esetében korlátozott számban beszélhetünk érdemi eredményekről, ugyanakkor relevanciájukból adódóan további kutatási fókuszt igényelnek.

\section{A reálopció-elmélet alapvetései}

A reálopciók definiálását célszerü a kifejezés szétszedésével kezdenünk, mitől lesznek opciók, és mitől lesznek reáliák? A reálopciós elmélet sok hasonlóságot mutat a pénzügyi opcióelmélettel. Az opció kifejezés fontos az elmélet eredetének és korlátainak megértése szempontjából. Az opció jog, és semmiképpen sem kötelezettség egy jövőbeli konkrét cselekvés, konkrét áron történő végrehajtásához. A pénzügyi opciókhoz hasonlóan a reálopciók birtoklásával szintén jogok, és nem kötelességek, tehát olyan működési-fedezeti mechanizmusok tulajdonosaivá válunk, melyek a rugalmasságot, a környezetre való aktív reagálás képességét viszik be a menedzseri eszköztárba azzal, hogy a pénzügyi termékeknél jelen lévő lehetőségeket fizikai eszközökre értelmezik.

Mielőtt folytatnánk a definiálást, hogyan juthatunk hozzá ilyen jogokhoz? Egyes esetekben e jogok szerződések eredményeként jönnek létre (pl.: szabadalom, közös vezetésű vállalat, elsőbbségi hozzáférés beruházási lehetőségekhez), míg más esetekben a vállalat által birtokolt, idioszinkratikus, speciális tudás eredményeként (pl.: csinálva tanulás, kutatás-fejlesztés stb.).

Térjünk rá a reáliákra! A piaci környezet dinamikus változásának hatására Myers (1977) használta elsőként a reálopció kifejezést. A vállalat jövőbeni beruházási stratégiájától tette függővé a vállalat értékét, melyhez két eszközcsoportot különböztetett meg reáleszközök és reálopciók formájában. Reáleszközöknek nevezte a vállalat beruházási stratégiájától független piaci értékeket, reálopcióknak pedig azokat a lehetőségeket, amelyek a reáleszközök megszerzését teszik lehetővé egy jövőbeni időpontban vagy időpontig, kedvező feltételek mellett.

Egy vállalat befektetési döntései eredményeként beszerzett eszközeinek a többsége a fogyasztói kereslet kielégítése érdekében előállított termék, illetve nyújtott szolgáltatás során felhasznált, alkalmazott, müködtetett reáleszközöket testesít meg. A reáleszközöket csoportosíthatjuk tárgyiasultságuk szerint materiális (ingatlan, gépek, berendezések, járművek stb.) és immateriális (know-how, márkanév, szabadalmi jog stb.) javakra; míg lejárat, illetve használati idő szerint befektetett és forgóeszközökre (Banyár et al., 2010). A tartósan lekötött reáleszközökbe történő befektetés vizsgálata kiemelt területe a befektetési döntéseknek, ezeket nevezzük beruházási döntéseknek, a reáleszközök létesítésére irányuló projekteket a továbbiakban beruházásnak. Egy beruházásra jellemző, hogy egy ismert tőkekiadás eredményeként a jövőben ismeretlen pénzáramokat realizálunk. A beruházás megvalósítója, 
a beruházás tulajdonosa lemondhat a pénzáramokról például abban az esetben, ha a beruházás leállításából eredő pénzáramok meghaladják a beruházásból az adott időpontot követően realizálható jövőbeli pénzáramokat. Egy pénzpiaci hasonlattal élve, mindez megfeleltethető egy részvény vásárlásának tranzakciós költségek mellett. A részvény birtoklásából a tulajdonos pénzáramokat (osztalékot) realizál. Amennyiben a befektető megítélése szerint a részvény alulértékelt, és a jelenlegi piaci ára alacsonyabb, mint a belőle származó jövőbeli osztalékáramok jelenértékösszege, akkor a befektető további részvénybeszerzés mellett fog dönteni. Ugyanakkor, a részvény túlértékeltsége esetén a részvény eladását választja. A befektető e vételi (long) és eladási (short) pozíciók nyitását végtelenszer kezdeményezheti. Hasonló példa lehet a gyárlétesítmény létrehozásának esete, mely a jelenben pénzkiáramlást, ugyanakkor a jövőben a gyártott termék iránti kereslet által befolyásolt pénz be- és kiáramlásokat eredményez. Egy bizonyos jövőbeli időpontban az előállított termék iránti kereslet csökkenni fog, vagy hasonló pénzáramhatást eredményezve további versenytársak jelennek meg a piacon. Ezen a ponton a befektető kísértést érezhet a projekt elvetésére, mely minden bizonnyal költséggel jár számára. Egy ilyen döntést csupán egy alkalommal hozhat meg. Mivel a befektető nem köteles sem beruházást kezdeményezni, sem meglévő, futó projektet elvetni, a problémát mérlegelésen alapulónak, diszkrecionálisnak tekintjük.

A számos hasonlóság, közös elméleti gyökerek ellenére a pénzügyi és reálopciók kapcsolatára tekintve a különbségek dominálnak. A reálopciók értékelését elsősorban az alaptermék nyilvános piacának gyakori hiánya nehezíti meg, de a pénzügyi opciókra jellemző csupán pénzügyi alkalmazási területtel szembeni, kvázi az élet, gazdaság minden területén megjelenő alkalmazásából adódóan a reálopciók bizonytalansági tényezők garmadája által befolyásolt. Továbbá a pénzügyi opciókkal ellentétben a reálopciók lehívása oligopolisztikus keretek között hatással lehet a többi opciótulajdonosra (versenytársakra). Ugyanazon lehetőség értéke különbözhet vállalatonként a heterogén vállalati viselkedésnek köszönhetően ( $\mathrm{pl}$.: egy alacsonyabb vállalatspecifikus kockázattal sújtott vállalat kihasználhatja az elsőként piacra lépés előnyét).

\section{A bizonytalanság}

A reálopciók értelmezésének, értékelésének komplexitását a bizonytalansági tényezők számossága okozza (McGrath - MacMillan, 2000). Az az alapvető döntési aszimmetria, mely a jövőbeli döntést (pl.: beruházni, bővíteni, szűkíteni stb.) csupán a döntéshozó számára kedvező körülmények esetén eredményezi, bizonytalanság jelenlétekor aszimmetriát teremt a vállalati kimenetek szempontjából egyaránt. A bizonytalanság feltárásával a vállalat képes lehet saját kockázatkitettségének csökkentésére, ugyanakkor az értékteremtésre egyaránt. Bélyácz (2010) részletesen elemezte a kockázat és bizonytalanság jelenségét, e tanulmány a továbbiakban a mérhető bizonytalansággal, közkeletübb kifejezéssel kockázattal foglalkozik. Értékteremtés valósulhat meg, ha egy vállalat megtalálja az alsóági (negatív) kockázat (downside risk) csökkentésének módját, a bizonytalanság kedvező, felsőági (upside) hatásainak fenntartása mellett (Billington - Kuper, 2000). Például egy beruházási vételi reálopció esetében annak tulajdonosa képes a felsőági lehetőségek kihasználására az alsóági veszteségek korlátozása mellett (nem lehívás). A reálopciós elemzések során célszerü csupán azokat a paramétereket vizsgálni, amelyek hatással vannak a reálopció jövőbeli pénzáramaira, valamint az alaptermék értékére (Amram - Kulatilaka, 1999). Minél jelentősebb a bizonytalanság, annál értékesebb ceteris paribus a reálopció, vagyis az adott cselekvési játéktér. A releváns bizonytalanságok halmaza alapvetően a vállalat belső és külső befolyásoló tényezőinek függvénye. A legtágabb kategorizálás szerint beszélhetünk exogén (piaci kereslet, verseny bizonytalanság) és endogén bizonytalansági tényezőkről (technológiai bizonytalanság, viselkedési bizonytalanság). Copeland és Antikarov (2003) a nagy számosságú bizonytalansági tényező kezelése érdekében egy ún. 80:20 szabályt ajánl, mely szerint a menedzsmentnek célszerü azon három-négy bizonytalansági forrásra koncentrálnia, amelyek leginkább hatnak a reálopció által generált pénzáramokra.

\section{Az irreverzibilitás}

A pénzügyi opciókkal ellentétben a reálopciók likviditása korlátos, azok szervezett piaci körülmények között nem minden esetben kereskedhetőek, eszköz- vagy vállalatspecifikusak, ezáltal részben irreverzibilisek, mely olyan kihívások elé állítja a döntéshozókat, mint az információs aszimmetria, az útfüggőség, vagy a tökéletlen tulajdonviszonyok. Az irreverzibilitás, vagy visszafordíthatatlanság jellemző az erősen tőkeintenzív, jelentős pénzügyi elköteleződéssel járó reál befektetésekre, vagyis amint e beruházási projektet megvalósították, annak tökeköltségét elsüllyedt költségnek kell tekintenünk, hiszen e nagy volumenü projektek esetében viszonylag jelentéktelen annak a valószínüsége, hogy a beruházó a projekt tárgyát más célokra használhatja fel, illetve nominál értékéhez képest szignifikáns veszteségek nélkül likvidálhatja azt. A viszszafordíthatatlanság mértékét az elsüllyedt költségeknek teljes befektetett tőkéhez viszonyított arányával közelíthetjük.

\section{A rugalmasság}

A reálopciók esetében az aktív, változó bizonytalansági körülményekre való reagálás állapotát nevezzük rugalmasságnak. Jellemzően e menedzseri flexibilitásnak két típusát különböztetjük meg, az időbeli rugalmasságot, valamint a termelési rugalmasságot (ezekröl részletesebben A reálopciós típusok alfejezetben). A rugalmasság esetében rendelkezésre álló, elsősorban tisztán kvalitatív, részben kvantitatív értékelési módszertan egyrészt magában rejti a tervezett beruházás pozitív irányú manipulációjának lehetőségét, másrészt annak negatív irányú befolyásolásának veszélyét egyaránt. Előbbi esetben a hagyományos döntéstámogatási eszköztár által megragadni képtelen rugalmasság figyelembevétele, beárazása történhet meg, mellyel a most vagy soha jellegü döntések 
eredményeként helytelenül elutasított (alulértékelt) értékteremtő projektek elfogadására kerülhet sor, míg az utóbbi eset alatt az árnyék-, illetve egyéb ki-, illetve felépített opciók indokolatlan túlértékelését, közvetve a szub-optimális menedzsmentdöntéseket értjük (Adner - Levinthal, 2004). Következésképpen a megfelelö döntéstámogatás érdekében a rugalmasság vizsgálatakor a beruházó kvantitatív tényeken alapuló objektív ítéletet kell, hogy hozzon.

\section{Reálopciók a döntéshozatalban}

Bár az utóbbi negyven évben egyre több vállalat alkalmazza a vállalati döntéshozatal, kockázatmenedzsment, illetve értékelési tevékenysége során a reálopciókat, a reálopciós logika értelmezése, a reálopciók megjelenése a döntéshozatalban vállalatonként eltérő. A leggyakrabban hivatkozott kategorizálás máig Triantis és Borison (2001) nevéhez füződik, akik a vállalatok által alkalmazott reálopciós döntéshozatali megközelítéseket három osztályba sorolják:

- első szint: a reálopciós gondolkodás, mely szerint a vállalatok a reálopciós logikát elsősorban a döntési problémák kvalitatív elemzésekor használják, magának a problémának, illetve az alternatíváknak értelmezése, illetve kommunikálása során (Cyert - March, 1963; Dosi, 1982; Nelson - Winter, 1982; Penrose, 1959); tehát a reálopciós érvelés, a reálopciók a vállalati döntéshozók gondolkodását tükrözik,

- második szint: reálopció mint elemzőeszköztár az opcióárazási modellek alkalmazására épül, az azonosítható, specifikálható opciós karakterisztikával rendelkező projektek esetében bevetve (Dixit - Pindyck, 1994; Trigeorgis, 1997),

- harmadik szint: reálopció mint szervezeti folyamat, viselkedési perspektíva: a reálopciót egy jelentősebb folyamat részeként alkalmazzák, mint egy, a stratégiai opciókat azonosító és kihasználó menedzsmenteszköz (Luehrman, 1998; Mcgrath, 1997).
A továbbiakban a harmadik szint szemszögéből, a reálopciós módszertan stratégiai menedzsment alkalmazási vetületét vizsgálom. A szemlélettel hazai forrásokban csupán Rózsa (2008) munkáiban, továbbá jellemzően német forrásokban (Hommel - Pritsch, 1999; Hungenberg, 2001; Hutzschenreuter, 2001; Pritsch - Weber, 2003;) találkoztam. Ezek a reálopció-elmélet operacionalizálását az 1 . táblázatnak megfelelően, a már birtokolt, illetve az újonnan feltárandó reálopciók azonosításán, ezt követően azok értékelésén, végül azok hatékony menedzsmentjén keresztül állítják a stratégiai értékteremtés, a stratégiai döntések szolgálatába. Ebben a kvázi reálopciós életciklusmodellben (Trigeorgis - Reuer, 2017) a vállalat korábbi stratégiai döntéseinek eredményeként létrejövő reálopciók (árnyékopciók), majd a beszerezhető, kifejleszthető, elsősorban egyéni kompetenciákra támaszkodó reálopció azonosítási lépéseket követően, a vállalat szervezeti és viselkedési karakterisztikái alapján azok hatékony menedzselésébe kezd a végső, jellemzően saját belátás szerinti, intuícióalapú lehívási döntések meghozatala előtt. E diszkrecionalitás hátterében a korábban említett, a döntéshozó rendelkezésére álló menedzseri flexibilitás, az opciókhoz köthető döntési szabadság áll, mely kvalitatív, szemi-kvantitatív és kvantitatív döntéstámogatási eszközök bevonása esetén is eredményezhet a döntési javaslattal megegyező, de akár attól eltérő magatartást.

A következőkben az 1. táblázat mentén haladva ismertetem a legfőbb reálopciós típusokat, értékmozgatókat, értékelési eljárásokat, valamint a reálopciók megjelenését a vállalati stratégiai folyamatokban, illetve döntéshozatalban.

\section{A reálopciók felismerése, azonosítása}

Az első lépésben javasolt a vállalatban, a vállalat környezetében létező reálopciók feltárása. A keresés kiindulópontja a vállalat saját erőforrásbázisa. Egy teljességre törekvő feltárás érdekében javasolt a belső stratégiai vizsgálatokként ismert keretrendszerekhez visszanyúlni, úgy, mint a porteri értékteremtési lánchoz (Porter, 2000), vagy egyéb vállalatirányítási rendszerekhez (Hungenberg, 2001). Mi-

A stratégiai reálopció-menedzsment folyamatábrája

\begin{tabular}{|c|c|c|c|}
\hline $\begin{array}{c}\text { 1. lépés } \\
\text { Reálopciók azonosítása }\end{array}$ & $\begin{array}{c}\text { 2. lépés } \\
\text { Reálopciók értékelése }\end{array}$ & $\begin{array}{l}\text { 3. lépés Reálopciók hatékony } \\
\text { menedzselése }\end{array}$ & $\begin{array}{l}\text { 4. lépés } \\
\text { Lehívás }\end{array}$ \\
\hline STRATÉGIAI ELEMZÉS & $\begin{array}{l}\text { STRATÉGIAFORMÁLÁS ÉS } \\
\text { KIVÁLASZTÁS }\end{array}$ & STRATÉGIAALKALMAZÁS & STRATÉGIAI DÖNTÉS \\
\hline Árnyékopciók azonosítása & $\begin{array}{l}\text { Az értékelés paramétereinek } \\
\text { meghatározása }\end{array}$ & $\begin{array}{l}\text { Reálopciók közötti kölcsönha- } \\
\text { tások }\end{array}$ & Piacra lépés, piacelhagyás \\
\hline $\begin{array}{l}\text { Alap, önálló reálopciók azono- } \\
\text { sítása }\end{array}$ & $\begin{array}{c}\text { Értékelési modellek kiválasz- } \\
\text { tása }\end{array}$ & & Szakaszolás \\
\hline Összetett reálopciók azonosítása & Értékelés & & $\begin{array}{c}\text { Termelés változtatása, beszállí- } \\
\text { tók változtatása }\end{array}$ \\
\hline Reálopciók priorizálása & & & Időzítés stb. \\
\hline EGYÉNI KOMPETENCIÁK & & $\begin{array}{l}\text { SZERVEZETI, VISELKEDÉSI } \\
\text { KARAKTERISZTIKÁK }\end{array}$ & INTUÍCIÓK \\
\hline
\end{tabular}


vel a korábbi vállalati döntések, cselekvések, beruházások jövőbeli beruházási lehetőségeknek engednek teret, azokat befolyásolják, ezért egy időleges, átmeneti kapcsolat fedezhető fel a vállalat múltbeli és jövőbeli tevékenységei között. Ezen árnyék, vagy rejtett opciók jelensége folytán az értékmaximalizáló vállalatnak fel kell tárnia és értékelnie ezeket a kapcsolatokat és lehetőségeket. Azok a vállalatok, akik meglévő, korábbi beruházásokból származó lehetőségekkel nem rendelkeznek, vagy nem veszik számba azokat, nem azonos, nem a potenciális legjobb jövőbeli beruházásilehetőség-palettához férnek hozzá.

A vállalatban már létező reálopciók azonosítását követően az értékvezérelt menedzsment újabb kihívással találja szembe magát, amikor a fenntartható értéknövekedés érdekében újabb reálopciók felkutatásába kezd (Baghai et al., 1999). A reálopció-elmélet nem ajánl fel direkt útmutatást a stratégiai menedzsment számára a reálopciók operacionalizálására vonatkozóan. Az egyetlen ajánlás szerint kockázatos környezetben érdemes reálopciók formájában felépíteni a cselekvési rugalmasságot, annak érdekében, hogy negatív kimenetelü események bekövetkezése ellen a vállalat be legyen biztosítva, amellett, hogy a pozitív kimenetek kihasználhatóságát is biztosítja (Bockemühl, 2001; Pritsch, 2000). Vagyis szignifikáns bizonytalanságok jelenlétekor a stabil, fókuszált és ezáltal elhivatott stratégiával szemben elönyösebb a szakaszos, diverzifikált reálopciók birtoklása (McGrath, 1999; Copeland - Howe, 2002). A reálopció-elmélet nem specifikálja, hogy ezeket az opciókat konkrétan hogyan kell fel-, illetve kiépíteni. Ugyanakkor a beruházó a kedvező lehetőségek portfólióját alakíthatja ki, a reálopciók létjogosultságát megteremtő tényezőknek, a bizonytalanságnak, az irreverzibilitásnak, valamint a rugalmasságnak a dimenziói segítségével (lásd 1. ábra).

1. ábra

\section{A kedvező lehetőségek portfóliója}

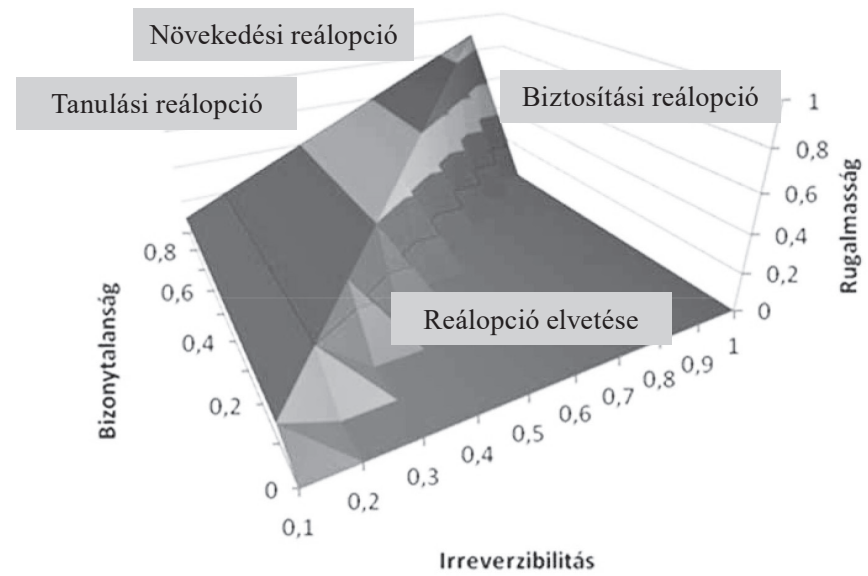

Forrás: saját szerkesztés

Az azonnali elköteleződés és a rugalmasság átváltási kapcsolat megfelelő menedzselése a vállalati versenyképesség meghatározó tényezője, mely a bizonytalanság és döntési rugalmasság által létrehozott lehetőséghalmaz eredménye
(Chi, 2000). A vállalatok tehát folyamatosan egy beruházás azonnali megvalósítása és a rugalmasság ki-, illetve felépítése közötti dinamikus trade-off-fal találják szembe magukat. Amennyiben relatíve csekély bizonytalanság jellemzi a döntési helyzetet, valamint a menedzsment a döntés tárgyát alacsony elsüllyedt költség arányúnak nyilvánítja, akkor a rugalmasság mértékétől függetlenül kedvezőbbnek tünik a reálopciós elemzés elvetése. Ebben az esetben ajánlott az egyéb, diszkontált pénzáramalapú projektértékelési technikákat bevetni a döntéshozatal támogatása érdekében.

A bizonytalanság, az aszimmetrikus információk, a tanulási hatás, a szakaszos kivitelezés lehetősége egymásra is hatással lesznek és különbözőképpen befolyásolják a rugalmasság és elköteleződés közötti átváltási kapcsolatot. A trade-off intenzitása mind exogén, mind endogén bizonytalansági tényezők által befolyásolt. Mivel a bizonytalanság az elköteleződés által létrehozott lehetőségek értékét növelni fogja, a nagyobb fokú bizonytalanság nem feltétlenül tántorítja el a vállalatokat az elköteleződéstől, vagyis a korai megvalósítástól. Például egy rugalmas növekedési stratégia egy egyértelmü first mover előnyökkel és a csinálva tanulással jellemezhető iparágban kevésbé lesz értékes. Az elsőnek lépéselőnye és a kezdeti nagy volumenü tőkekiadásokkal jellemezhető stratégiai elköteleződés visszatarthatja a versenytársakat, de mindenesetre hatással lesz azok viselkedésére (Smit - Trigeorgis, 2007). Az elsőnek lépők tulajdon-, illetve kizárólagossági jogokat szerezhetnek szabadalmak, licencek formájában annak érdekében, hogy megvédjék, illetve kisajátítsák a jövőbeli növekedési lehetőségeket. Mindez egyébként azt jelzi, hogy a korai elköteleződés tulajdonképpen ösztönzi a jövőbeli rugalmasságot. Vagyis a nagyfokú bizonytalanság csupán abban az esetben tántorítja el a vállalatokat az azonnali elköteleződéstöl és projektkivitelezéstől, amennyiben egyetlen, irreverzibilis, előnyökkel nem járó korai lehívással, elhanyagolható tanulási hatással, jövőbeli lehetőséggel, és egyéb stratégiai first-mover elönyökkel jellemezhető projektről van szó.

A bizonytalanság, számosságának, mértékének, valamint az elsüllyedt költségek arányának növekedtével a reálopciós metodika előtérbe kerül. A rugalmasság különböző szintjein a reálopcióknak különböző típusait érdemes bevetni a kockázatcsökkentés, valamint az értékteremtés érdekében.

Ezen a ponton térnék rá a reálopciós típusok ismertetésére. A reálopciók típusainak egy viszonylag szűkebb, és egy gazdagabb tipologizálását különböztethetjük meg attól függően, hogy a projektmüködtetők milyen mértékü szabadságot kapnak az eszköz vagy a projekt kezelése során. A reálopciók jellemzően két dimenzió mentén jöttek létre: az időzítésre koncentrálva, valamint a kiterjedés mentén, ugyanakkor amilyen hasznosnak tünik az „opciós nyelvezet“ a vállalatban jelenlévő cselekvési játékterek kvalitatív leírására, a reálopcióknak stratégiai jelentőségét, és egyben egy hosszú távú vállalati cél mögött felsorakoztatásának lehetőségét Copeland és Keenan (1998) kategorizálása hangsúlyozza a leginkább, akik növekedési, tanulási és biztosítási reálopciókat különböztetnek 
meg. A reálopciós irodalmak hol az előbbi, hol az utóbbi, sok esetben ad hoc jellegü típusismertetésének összefésülési céljával jött létre a 2. táblázat, mely a két csoportosítási szempontrendszer közös metszeteinek azonosításán keresztül mutatja be az alapvető stand-alone típusokat.

2. táblázat

A reálopciós típusok kategorizálása a flexibilitás, valamint a vállalati stratégiai szempontok figyelembevételével

\begin{tabular}{|c|c|c|}
\hline & $\begin{array}{l}\text { IDŐBELI RU- } \\
\text { GALMASSÁG- } \\
\text { RA ÉPÜLŐ RE- } \\
\text { ÁLOPCIÓK }\end{array}$ & $\begin{array}{c}\text { TERMELÉSI/ } \\
\text { KITERJEDÉS- } \\
\text { BELI RUGAL- } \\
\text { MASSÁGRA } \\
\text { ÉPÜLÖ } \\
\text { REÁLOPCIÓK }\end{array}$ \\
\hline $\begin{array}{l}\text { NÖVEKEDÉSI } \\
\text { REÁLOPCIÓ }\end{array}$ & & $\begin{array}{l}\text { (1) Növekedési } \\
\text { reálopció }\end{array}$ \\
\hline $\begin{array}{l}\text { TANULÁSI RE- } \\
\text { ÁLOPCIÓ }\end{array}$ & $\begin{array}{l}\text { (2) Halasztási/ } \\
\text { időzítési reálopció } \\
\text { (3) Elvetési } \\
\text { reálopció } \\
\text { (4) Szakaszos } \\
\text { reálopció }\end{array}$ & $\begin{array}{l}\text { (5) Feltárási } \\
\text { reálopció }\end{array}$ \\
\hline $\begin{array}{l}\text { BIZTOSÍTÁSI } \\
\text { REÁLOPCIÓ }\end{array}$ & $\begin{array}{l}\text { (6) Leállítási/újra- } \\
\text { indítási reálopció }\end{array}$ & $\begin{array}{l}\text { (7) Méretváltoz- } \\
\text { tatásra irányuló } \\
\text { (szűkítési, bővíté- } \\
\text { si) reálopció } \\
\text { (8) Összetétel (in- } \\
\text { put/output/beszál- } \\
\text { lító) változtatásra } \\
\text { irányuló reálopció } \\
\text { (9) Kiszervezési } \\
\text { reálopció }\end{array}$ \\
\hline
\end{tabular}

Forrás: saját szerkesztés (Trigeorgis, 1996; Amram - Kulatilaka, 1998; Benaroch, 2002; Copeland - Antikarov, 2003).

Az időbeli dimenzión belül a tanulási reálopciós kategóriába sorolható halasztási/időzítési reálopciókat és elvetési reálopciókat, míg a biztosítási célú reálopciók közül leállítási/újraindítási reálopciókat különböztetünk meg. Az ún. kiterjedési vagy termelési dimenzión belül beszélhetünk növekedési reálopciókról, a tanulási céllal azonosított, létrehozott feltárási reálopciókról, valamint a biztosítási csoport méretváltoztatásra, vagy összetétel-változtatásra irányuló reálopcióiról, illetve a kiszervezési reálopciókról (Trigeorgis, 1996; Amram - Kulatilaka, 1998; Benaroch, 2002; Copeland - Antikarov, 2003). A továbbiakban e típusok alapvetö tulajdonságait ismertetem.

(1) A növekedési reálopció szerint egy adott beruházás előfutára vagy kiindulási alapja lehet egymással összefüggő projektek láncolatának, megnyitva ezzel jövőbeli növekedési lehetőségeket (pl.: új projektek, új folyamatok megvalósítása; új piacpenetráció; az alapkompetenciák erősítése) (Kester, 1984). Ezeket a források stratégiai növekedési lehetőségeknek, vagy innovációs opcióknak is nevezik. A növekedési reálopciók célja sok esetben nem, illetve nem csupán az azonnali értékteremtés, sokkal inkább jövőbeli üzleti lehetőségek előteremtése.
A menedzsment számára a növekedési opciók jelentik a kiindulási alapot ahhoz, hogy pótlólagos projektek, illetőleg a meglévő erőforrások kiterjesztése révén a gazdasági környezet pozitív fejlődéséből profitra tegyenek szert (Courtney et al., 2001; Hungenberg, 2001). A vállalati gyakorlatban ezek az opciók a vállalat speciális humántőkéjén, technológiai tudásán, vagy egy domináns piaci pozíción alapulhatnak (Witt, 2003).

(2) Egy tanulási típusú reálopció lehetővé teszi a befektetési döntéshozatal kitolását, csökkenti annak a kockázatát, hogy a menedzsment hiányos információk alapján visszafordíthatatlan döntéseket hozzon, és így kedvezötlen következményeket szenvedjen el (Brach, 2003; Pritsch, 2000). A menedzserek beruházások időzítésére vonatkozó flexibilitása ezen információk beszerzésének egy fontos módja, más szóval kifizetendő lehet várni addig, amíg a bizonytalanságot okozó körülmények megszünnek, következésképpen az a vállalat, amely a beruházások időzítésének képességét, az időzítési rugalmasságát már birtokolja azért, hogy feladja ezt a rugalmasságot jogosan vár el pénzügyi kompenzációt az azonnali megvalósítás esetében, az új információkra való várakozás helyett (Blyth et al., 2007).

(3) Amennyiben a piaci körülmények tartósan és jelentősen romlanak, a menedzsment dönthet az adott projekt termelésének, a projekt müködtetésének tartós leállítása mellett, a benne foglalt eszközök, tőkejavak likvidálása, majd a likvidálásból származó összegek máshol történő felhasználása mellett (Myers - Majd, 1990; Hubbard, 1994). Az elvetésnek e lehetősége csak abban az esetben áll fenn, az elvetési reálopció csak akkor létezik, ha a beruházási projekt teljes irreverzibilitása nem érvényesül. Vagyis az elvetési opció létezésének egy következménye a beruházások részleges visszafordíthatósága lesz. Az elvetési opciók értékelése kapcsán a legnagyobb kihívást az elvetés optimális időpontjának megválasztása jelenti. Robichek és van Horne (1967) javaslata szerint a projektet akkor érdemes felszámolni, ha a likvidálásból származó bevétel és az elvetési költségek különbsége meghaladja a megszünő pénzáramok jelenértékét.

(4) Mivel a termelés, vagy a későbbi termelés elérhetőségét determináló tevékenységek nem halaszthatóak a végtelenségig, a halasztási stratégia gyakran együtt jár a menedzseri flexibilitás gyakorlásának egy következő szintjével, a döntés egymást követő szakaszokra darabolásával (Trigeorgis, 1996). Amennyiben egy beruházásra képesek vagyunk úgy tekinteni, mint pénzkiáramlások egymás utáni sokaságára, akkor a szakaszos reálopció lehetőséget teremt az egyes fázisokat követően beszerzett kedvezőtlen információk esetén a beruházás, illetve projekt elvetésére, vagyis a szakaszos reálopciók lényegében mind a halasztási, mind az elvetési reálopciókkal rokon tulajdonságokat hordoznak. A különbség, hogy egy beruházásnak (egy szakasznak) már léteznie kell, hogy újabb információk birtokába juthassunk. A szakaszos fejlesztésnek tanulási és bizonytalanságcsökkentő hatása lesz.

(5) A kiterjedési dimenziót tekintve, a termelési rugalmasság mentén, választások sokaságának bevezetése történik. A feltárási reálopció révén lehetővé válik egy 
projekt prototípus vagy pilot (bevezető) szintű megvalósítása, ahol a prototípus, illetve pilot költségei arányosak a teljes projekt megvalósítás költségével. A prototípus eredményeit figyelembe véve a menedzsment dönthet a projekt megvalósítása és elvetése mellett is.

(6) A biztositási opciók a kedvezőtlen keresleti, vagy áralakulásra való reagálás lehetőségét tárják fel a menedzsment számára időbeli és/vagy operatív alkalmazkodás formájában. A növekedési opciókkal ellentétben a biztosítási reálopciók védik a vállalatot az esetleges veszteségkockázatokkal szemben olyan módon, hogy azok elkerüljék pénzáramaik csökkenését (Copeland - Hove, 2002). Leállitási és újrainditási reálopciókról a biztosítási típusú reálopciós ügyleteken belül jellemzően a kedvezőtlenné váló piaci feltételek esetében beszélhetünk, amikor a vállalat a termelés leállítása mellett dönthet, az esetleges újraindítás lehetőségének nyitva hagyása mellett. A piaci helyzet javulásakor végrehajthatja a termelés újraindításába irányuló befektetést. A leállítási és újraindítási reálopció lényegében nem más, mint két egymással összekapcsolt lehetőség. A leállítási és újraindítási reálopció adekvát értékelésének kulcsa a lezárási és újraindítási költségek helyes azonosítása (McDonald - Siegel, 1985; Brennan - Schwartz, 1978).

(7) A méretváltoztatásra irányuló (bővitési, összehúzódási) reálopciókban rejlő rugalmassággal bármikor megváltoztathatjuk a projekt méretét a piaci igényekhez mérten. A bővítési reálopció azt a lehetőséget tükrözi, hogy egy beruházási projekt hatóköre jó piaci helyzet és kedvező jövedelmezőség esetében az adott beruházás értékét képes növelni. Ez azt jelenti, hogy a projektek méretét a piaci adottságokhoz lehet igazítani. Nem összetévesztendő a bővítési reálopció a növekedési reálopcióval, hiszen ebben a konkrét esetben a kérdéses projekt még nincs lezárva. Nem indul el újabb önálló projekt, hanem csak a futó projektek méretét növelik. Az összehúzási reálopció esetében egy (veszteséges) projekt méretének, hatókörének korlátozására vonatkozó lehetőségeit mérlegeli a vállalkozás. A már nem nyereséges projektrész megszüntetése legalább olyan fontos vezetői lépés, mint az innovációk menedzselése (Risak - Grün, 1985). Az összehúzódási reálopció sokban hasonlít az elvetési reálopcióra. Mindkét opciót eladási lehetőségként értelmezhetjük, azonban míg az összehúzódási reálopció csak egy része a teljes projektnek, addig az elvetési reálopció esetében a teljes projektleállást mérlegeljük (Trigeorgis Mason, 1987; Pindyck, 2000).

(8) Az összetétel-változtatásra irányuló reálopció lehetővé teszi a projekt müködtető számára, hogy az eszközön a piaci követelményeket követve átváltson egy másik müködési modellre - természetesen a tranzakciós költségek megfizetése mellett (Margrabe, 1978; Kensinger, 1987). Ha változik a gyártott termék ára, vagy az iránta való kereslet, akkor a gyártulajdonos megváltoztathatja a gyár termelési kosarát, vagy ugyanazt a kimenetet nyújtja, megváltoztatott alapanyagokból (Hommel, 2000). Nem elhanyagolhatók azok a költségek, amelyek az egyik output változatról (illetve input változatról) a másikra való átállásnál jelentkeznek. E reálopciók értékelésének kritikus pontja az átállási költségek helyes megragadása (Hartmann, 2006).
(9) Egy beruházás megvalósításához szükséges erőforrásokat kiszervezhetjük külső feleknek, így áthárítva a váratlan eseményekből adódó költségek, illetve a projekt vállalaton belüli megvalósításra-képtelenségnek kockázatát. Ezeket a reálopciókat nevezzük kiszervezési vagy outsourcing reálopcióknak (Richmond - Seidmann, 1993).

A reálopciós típusok ismeretében visszatérve a kedvező lehetőségek portfóliójához, közepes rugalmassági szinten elsősorban a tanulási, kifejezetten kockázatcsökkentési célzattal életre keltett reálopciók alkalmazása ajánlott. A tanulási reálopciók lehetővé teszik a lehető legkisebb kezdeti elköteleződést a projekt iránt, korlátozva a potenciális veszteségkockázatokat. A bizonytalanság alacsony szintje párosulva a befektetés nagyfokú visszafordíthatatlanságával, a tanulási vagy biztosítási reálopciók alkalmazását vonja maga után a beruházó rugalmasságának függvényében. Az igazi fenyegetés ebben az esetben abból adódik, hogy kedvezőtlen események bekövetkezése esetében a végrehajtott beruházás visszafordíthatatlan. A biztosítási reálopciók a projekt alakíthatóságának rugalmasságával a veszteségminimalizálás legmegfelelőbb eszközei. A termelési, müködési flexibilitás megjelenésével a biztosítási reálopciók a kockázatkezelés mellett az értékteremtési folyamat részeseivé is válhatnak; míg az abszolút irreverzibilis, szignifikáns kockázatnak kitett, jelentős menedzseri flexibilitás mellett végrehajtott beruházások jellemzően a növekedési reálopciók.

\section{A reálopciók értékelése}

Amennyiben sikerült az adott beruházónak azonosítania, illetve a szükséges erőforrások biztosítása, valamint piaci pozíciója révén felépítenie reálopciós bázisát, a következő lépés azoknak az értékteremtés szolgálatába állítása. Ennek első lépése az értékmozgatók azonosítása, melyek lényegében megegyeznek a reálopció értékét meghatározó tényezőkkel. Ezek közül is, ahogyan azt korábban láttuk, kiemelendő a bizonytalanság hatása, hiszen számos reálopciós irodalomban találkozunk azzal a kijelentéssel, hogy minél nagyobb bizonytalanság övezi az adott beruházást, annál nagyobb az adott reálopció értéke (Copeland et al., 2000; Amram - Howe, 2002; Broyles, 2003). Adner és Levinthal (2004) azonban az azonnali megvalósítás rugalmasság átváltási kapcsolat kvalitatív érvelésén túl operacionalizált keretek között is rávilágítottak, hogy az opcióelmélet e fundamentuma erősen félrevezető, az erre épülő menedzsmentgyakorlat pedig egyenesen hibás. A reálopció értékére pozitívan csak az „előnyös“ bizonytalanságok (felsőági bizonytalanságok) vállalása hathat, miközben az „elönytelen“ bizonytalanságok (alsóági bizonytalanságok) szignifikáns értékromboló hatásúak.

A következő lépés az azonosított értékteremtők közötti kölcsönhatások vizsgálata (lásd 3. táblázat). Az opció benső értékét meghatározó két paraméter, az alaptermék értéke, valamint a kötési ár a többi értékmozgató által befolyásolt, ugyanakkor mivel ök maguk e paraméterek, valamint piaci adottságok eredőjeként adódnak, így nem lesznek hatással az őket meghatározó értékdeterminánsokra. A kockázatmentes ráta szintén piaci adottságként az opció értékét meghatározó paraméterektől független. A 
futamidő, vagyis az opciós lehetőségkapu nyitva állásának időtartama az osztalék kifizetési ráta által determinált, hiszen utóbbi paraméter határozza meg a jövőbeli lehetöségekkel növelt vállalat- és/vagy projektértéket. Utóbbi ugyanakkor behatárolja a tulajdonosok számára kifizethető összegek nagyságát. Az opció futamideje hatással lesz a diszkontálás eredményeként az alaptermék értékére. Az alaptermék értéke emellett az osztalék kifizetési ráta, a volatilitás és a kockázatmentes ráta által determinált. A volatilitás a piaci adottságként érkező - kötési ár és alaptermék érték - determinánsok révén fejti ki hatását. Az upside bizonytalanság növekedése például (ceteris paribus) pozitívan hat az opciós értékre, ugyanakkor ez a diszkontálás során használt (kockázati prémiummal növelt kockázatmentes) kamatláb növekedéséhez, mindez pedig az alaptermék értékének csökkenéséhez vezethet.

\section{A reálopciós értékmozgatók és az opció értéke közötti kapcsolat, valamint az értékmozgatók közötti kölcsönhatások}

\begin{tabular}{|c|c|c|}
\hline $\begin{array}{c}\text { Értékmozgató } \\
\text { (jelölés); [moz- } \\
\text { gatók, melyek } \\
\text { befolyásolják az } \\
\text { értékét] }\end{array}$ & $\begin{array}{l}\text { VÉTELI TÍPUSÚ } \\
\text { REÁLOPCIÓ } \\
\text { [(1)-(2)-(4)-(5)-(6b)- } \\
\text { (7b)-(8)] }\end{array}$ & $\begin{array}{l}\text { ELADÁSI } \\
\text { TÍPUSÚ } \\
\text { REÁLOPCIÓ } \\
\text { [(3)-(6a)- } \\
\text { (7a)-(8)-(9)] }\end{array}$ \\
\hline Futamidő (t); [d] & + & + \\
\hline Kötési ár (X); [d; s] & - & + \\
\hline 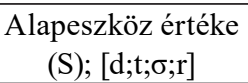 & + & - \\
\hline $\begin{array}{l}\text { Kockázatmentes } \\
\text { hozam }(\mathrm{rF})\end{array}$ & + & - \\
\hline $\begin{array}{c}\text { Bizonytalanság/ } \\
\text { volatilitás }(\sigma)\end{array}$ & + & + \\
\hline $\begin{array}{l}\text { Alapeszköz érté- } \\
\text { kének csökkenése } \\
\text { (d); [S] }\end{array}$ & - & + \\
\hline & \multicolumn{2}{|c|}{$\begin{array}{r}\text { ahol (1)-(2)-...stb. a reálopciós típusokat jelöli } \\
\text { a 2. táblázat számozásának megfelelöen } \\
\text { Forrás: saját szerkesztés }\end{array}$} \\
\hline
\end{tabular}

Az értékmozgatók közötti hierarchikus sorrend kialakításakor érdemes kiemelten kezelni azokat a generátorokat, melyek egységnyi változtatása a legnagyobb változást eredményezi a reálopció értékében (ceteris paribus), vagyis amely paraméterek változtatására a reálopció a legérzékenyebb, illetve melyek alakulását a menedzsment a legkevésbé képes befolyásolni (Leslie - Michaelis, 1997). Az elöbbi tulajdonságot a tényezők közötti kölcsönhatások integrálása érdekében célszerü forgatókönyv-elemzéssel, az utóbbit pedig kvalitatív érvekkel, elsősorban "scoring modellek" segítségével alátámasztani.

A 4. táblázat a reálopciós értékelési módszerek rendszerezését mutatja. Ezek az értékelési eljárások az adott döntési szituációban egyedi előnyökkel és hátrányokkal rendelkezhetnek. Emiatt fontos minden egyes esetben mérlegelni, hogy melyik módszer alkalmas leginkább az adott projekt döntéstámogatására. Az értékelési eljárásokkal szembeni legfontosabb követelmények az átláthatóság, az értékelés pontossága, az értékelési folyamat sokoldalúsága, a lehető legkisebb komplexitás, illetve az alkalmazó részéről a lehető legkisebb előzetes hozzáértési kívánalma (Az árazási modellek részletes tárgyalásától ezen a ponton eltekintek).

A szakma és a gyakorlat kettévált annak a kérdésnek a megválaszolásában, hogy a rendelkezésre álló árazási módszerek közül melyik bizonyul használhatóbbnak. A gyakorlati szakemberek sok esetben a Black-Scholes-modell mellett teszik le voksukat (Courtney et al., 2001), míg a legtöbb tudományos közlemény a binomiális-eljárást alkalmazza és javasolja. Kétségtelen, hogy az egyszerü alkalmazhatóság követelménye terén a Black-Scholes-modell (B/S) felülmúlja a binomiális eljárást (Amram - Kulatilaka, 1999), ugyanakkor fontos megjegyezni, hogy ezen értékelések során a reálopciók komplex modellezése programozási nyelvekre is támaszkodik, következésképpen relatíve magas módszertani ismereteket igényel (Dörner, 2003). Pontosan ez a komplexitás teszi a B/S-képlet merev struktúrájának és feltevéseinek adaptálását lehetetlenné (Copeland - Antikarov, 2003), vagyis modell transzparencia terén a binomiális eljárás a favorit. Bár a binomiális

Az opcióértékelési eljárások osztályozása

\begin{tabular}{|c|c|c|c|}
\hline \multicolumn{4}{|c|}{ Reálopció árazási módszerek } \\
\hline \multicolumn{2}{|c|}{ Analitikus módszerek } & \multicolumn{2}{|c|}{ Numerikus módszerek } \\
\hline Zárt modellek & Közelítő eljárások & $\begin{array}{c}\text { Parciális diff. egyenletre } \\
\text { épülő eljárások }\end{array}$ & $\begin{array}{c}\text { Sztochasztikus folyamatokat } \\
\text { közelítő eljárások }\end{array}$ \\
\hline Black-Scholes- formula & Geske-Johnson- modell & Numerikus integráció & Monte Carlo szimuláció \\
\hline Geske-Johnson- modell & & \multirow{4}{*}{$\begin{array}{l}\text { Explicit és implicit differencia- } \\
\text { sémák }\end{array}$} & Binomiális eljárás \\
\hline \multirow[t]{3}{*}{ Carr-modell } & & & Döntési fás eljárások \\
\hline & & & $\begin{array}{l}\text { Binomiális eljárás logaritmikus } \\
\text { transzformációval }\end{array}$ \\
\hline & & & Többfázisú döntési fák \\
\hline
\end{tabular}


eljárás precizitásban alulmarad a B/S-modellel szemben, eredményei az értékorientált vállalatirányítás számára elegendően pontosnak, könnyen illusztrálhatónak minősülnek, továbbá az eljárás grafikus ábrázolási lehetősége javítja a modelltranszparenciát és hozzáférhetőséget.

\section{A reálopciók hatékony menedzselése}

A reálopciós életciklusmodell harmadik lépéseként a reálopciók hatékony menedzselésével, azok fenntartásával, erősítésével találja szembe magát a vállalat. Ez a fejlesztési lépés elsősorban a stand-alone típusú reálopció-szemlélet kiterjesztését jelenti a reálopciók portfólió szempontú menedzselésére.

Az utóbbi évtizedben a reálopció-elmélet kiterjesztéseként a reálprojektekre értelmezett opciók mellett megjelent a reálprojektekben értelmezett opcionalitás fogalma. A projektekre értelmezett reálopciókra tekinthetünk úgy, mint egy-egy technológiára, reáliára kiírt pénzügyi opciókra, ahol maga a technológia fekete dobozként értelmezett. Ezzel szemben a projektekben vizsgált reálopciókat azért keltették életre, hogy az aktuális technológiai rendszert megváltoztassák (Wang - de Neufville, 2004).

Alapvető különbség a projektekre értelmezett és a projektekben foglalt reálopciók között, hogy míg az előbbiek jellemzően a beruházási lehetőségek értékelésével foglalkoznak, addig a projektekben foglalt reálopciók a rugalmasság kialakításával. A projektekre értelmezett reálopciók fókuszában a pontos értékmeghatározáson keresztüli döntéstámogatás áll, míg a projektekben foglalt reálopciók célja a korábban ismertetett „,belevágni, vagy sem" kérdések megválaszolása. Ebböl is következik, hogy az utóbbi esetben maga az értékmeghatározás, illetve kvantifikálás nem kap kiemelt szerepet, itt elsősorban a rugalmasságnak kvalitatív megragadásán van a hangsúly (lásd 5. táblázat).

\section{5. táblázat}

\section{Projektekre értelmezett versus projektekben} foglalt reálopciók

\begin{tabular}{c|c}
$\begin{array}{c}\text { PROJEKTEKRE } \\
\text { ERTELMEZETT } \\
\text { REÁLOPCIÓK }\end{array}$ & $\begin{array}{c}\text { PROJEKTEKBEN } \\
\text { FOGLALT REÁLOPCIÓK }\end{array}$ \\
\hline Lehetőségeket értékel & $\begin{array}{c}\text { A rugalmasságot elemzi, } \\
\text { értékeli }\end{array}$ \\
\hline A hangsúly az értékelésen & A hangsúly a döntésen \\
\hline $\begin{array}{c}\text { Viszonylag egyszerüen } \\
\text { definiálható }\end{array}$ & Nehezen megragadható \\
\hline $\begin{array}{c}\text { Az egymástól függés, } \\
\text { valamint az útfüggőség } \\
\text { kevésbé fontos kérdés }\end{array}$ & $\begin{array}{c}\text { Az egymástól függés, } \\
\text { valamint az útfüggőség } \\
\text { kulcskérdés }\end{array}$
\end{tabular}

Forrás: saját szerkesztés de Neufville (2002)، de Weck et al. (2004), Wang - de Neufville (2004) alapján

A projektekre értelmezett reálopciók definiálása viszonylag egyszerü feladat. Ezzel szemben ahhoz, hogy a projektekben foglalt reálopciókat felismerjük, azonosítsuk és megértsük, a technológia mély gazdasági, müszaki ismeretére van szükség. A legnagyobb problémát emellett a rugalmasság nehéz felismerhetőségének problémája okozza. Míg a projektekre értelmezett reálopciók esetében a technológiai, müszaki szempontok, a kölcsönhatások, az útfüggőség nem kapnak kiemelt figyelmet, addig a projektekben foglalt reálopciók esetében a komplex technológiai korlátok gyakran eredményeznek kölcsönhatásokat, útfüggőséget (de Weck et al., 2004).

Bár kétségtelen, hogy a reálopció-elmélet mára jól kidolgozott, széles körben elfogadott teóriává nőtte ki magát az egyedi projektértékelés szintjén, a különböző reáleszközökre irányuló opciók közötti kölcsönhatás azonosítására és számszerüsítésére koncentráló kutatási irányvonal a mai napig háttérbe szorul. Egy konkrét beruházási lehetőség értékelése egy kockázatos világban azonban figyelembe kell, hogy vegye az adott lehetőség sztochasztikus korrelációját minden egyéb lehetőséggel. Mindez azt jelenti, hogy egy optimális globális stratégiára csak akkor lelünk, ha minden releváns alternatívát szimultán figyelembe veszünk (Franke - Hax, 1998).

A reálopciók portfólióját vizsgálva jelen van egy tanulási hatás a más eszközökre kifejtett információs spill-overek formájában. Dias (2006) a portfólióelméletet, a korreláció szinergiában és tanulásban játszott szerepére hangsúlyt fektetve terjeszti ki a reálopciókra. A tanulási hatás értelmében egy opció lehívásával egy pozitív externáliát hozunk létre egy másik eszközre, úgy, hogy az első lehetőség kihasználása vonzóbbá vagy kevésbé vonzóvá teheti a másikat.

Elsőre a reálopciók értékadditivitását feltételezhetnénk, vagyis az eszközök összességének értéke megegyezik az egyenként vett eszközök értékének összegével. A reálopciók gyakran elválaszthatatlanul összekapcsolódnak az alaptermékkel, hiszen az alaptermék tulajdonjoga elöfeltétele az opció birtoklásának, és ezzel az opció lehívása hatással lesz az alaptermék értékére. A reálopciók összességének vizsgálatával, azok szakaszos, illetve együttes lehívásával a létrejövő méret- és változatossággazdaságosság hatására egyfajta szinergiahatás érvényesül. Két reálopció közötti szinergia szerint az egyesített reálopciós érték nagyobb, mint az egyedi reálopciós értékek összege. Mindez azt jelenti, hogy például a kutatás-fejlesztési beruházásokat méret növeléssel egyesíthetjük a projektek közötti szinergia kiaknázása érdekében, növelve az egyesített fejlesztés reálopciós értékét.

\section{A reálopciók lehívása}

A stratégiai reálopció-menedzsment negyedik és egyben utolsó lépése a reálopciók jellemzően menedzseri intuícióalapú lehívása, vagy azok érvényesítés nélküli megszünése. A stratégiai menedzsmentirodalom a reálopció-elméletre, elsősorban a pénzügyi opciós analógia reáliákra illesztésének korábban említett nehézségei folytán, elsősorban, mint stratégiai és intuícióalapú gondolkodásra, vagyis kvázi logikai, retorikai eszközre tekint, az analitikus modellezés mellőzésével. Egy reálopció értéket teremteni hangsúlyosan csupán a gyakorlása által képes. Ez a reálopciós típusok alapján jelentheti egy projekt megvalósítását, elvetését, szakaszolását, kiszervezését, méretének változtatását, a gyártott termék, nyújtott szolgáltatás 
input-output összetétel-változtatását stb. Amennyiben a beruházó nem ruház be, illetve megvárja a reálopció futamidejének lejártát, a vállalat a reálopció eddigiekben ismertetett menedzselésének, az értékteremtő reálopciók feltárási költségeinek következtében teljes bizonyossággal veszteséget realizál (Anderson, 2000).

\section{A reálopció-elmélet megjelenése a kutatási eredményekben}

A reálopciók myersi első említése óta (1977) számos tanulmány bizonyítja a reálopciós logika, módszertan alkalmazását a közölt kutatási eredmények kinyerése során, illetve számos munka fókuszált magára az elméletre, annak továbbfejlesztési lehetőségeire legyen szó módszertani, stratégiai, szervezeti vagy viselkedési aspektusokról. Egy 2017-es évben végzett absztrakt- és kulcsszóalapú kutatás során a Google Scholar ${ }^{\mathrm{TM}}$, a Google tudományos keresője segítségével, az angol „real options” kifejezésre keresve azonosítottam 1101 darab 2011 és 2016 között megjelent tanulmányt, melyek közül 951 volt angol nyelvü, valamint a gazdálkodástanhoz köthető' ${ }^{1}$ A 951 tanulmányalapú irodalomkutatás célja a releváns kutatási fókuszok, kutatási rések azonosítása mellett, a jelen tanulmányban vázolt stratégiai reálopció-elemzés lépéseinek igazolása, a leg- jobb gyakorlatokra, az ajánlott alkalmazási területekre való rávilágítás volt.

A két dimenziós kutatás során első lépésben a tanulmányokat a stratégiai döntéshozatali kategóriák (lásd 1 . táblázat) lencséjén keresztül vizsgáltam. Elsősorban e dimenzió elemzése érdekében volt szükség az absztraktok áttanulmányozására, hiszen a kvalitatív, kvantitatív és stratégiai kategóriákról, az alkalmazott módszertanról elsősorban ezekből, mint a kulcsszavakból nyerhetünk információt. Ennek eredményeként megállapítható, hogy az azonosított tanulmányok 61,2\%-a a kvantitatív, 33\%-a kvalitatív kategóriába sorolható és mindössze 5,8\% foglalkozik a stratégiai reálopció-elemzéssel. Általánosságban jellemző a reálopciós publikációkra a kvantitatív aspektusok dominanciája mind a kutatási eredmények, zömében mind a gyakorlati alkalmazás terén az értékelésre, a lehívási döntéstámogatásra koncentráló alkalmazással találkozunk. Bár a reálopciós logika, a kvalitatív érvelés a tanulmányok egyharmadára jellemző, ki kell emelnem, hogy a reálopciók azonosítása, ki-, illetve felépítése mellett az árnyékopciók, korábbi akciók jövőbeli lehetőségekre kifejtett hatásának vizsgálata egyáltalán nem jelenik meg a kutatási fókuszban. A stratégiai reálopció-elemzésre kapott eredmények alapján egyértelműen látszik a jövőbeli kutatási igény: a reálopciók portfólió

6. táblázat

A reálopciós kutatási eredmények döntéshozatali kategóriák és alkalmazási területek szerinti megoszlása

\begin{tabular}{|c|c|c|c|c|}
\hline & & $\begin{array}{l}\text { Reálopciós } \\
\text { gondolkodás }\end{array}$ & $\begin{array}{l}\text { Reálopció mint } \\
\text { elemző eszköztár }\end{array}$ & $\begin{array}{c}\text { Reálopció mint } \\
\text { szervezeti folyamat }\end{array}$ \\
\hline & \multirow[t]{2}{*}{$100,0 \%$} & $\begin{array}{l}\text { Kvalitativ reálopció- } \\
\text { elemzés }\end{array}$ & $\begin{array}{c}\text { Kvantitativ } \\
\text { reálopció-elemzés }\end{array}$ & $\begin{array}{c}\text { Stratégiai } \\
\text { reálopció-elemzés }\end{array}$ \\
\hline & & $33,0 \%$ & $61,2 \%$ & $5,8 \%$ \\
\hline Általános alkalmazás & $42,3 \%$ & $38,0 \%$ & $39,2 \%$ & $100,0 \%$ \\
\hline Villamosenergia-szektor & $14,9 \%$ & $7,7 \%$ & $20,1 \%$ & $0,0 \%$ \\
\hline Termelésmenedzsment & $8,0 \%$ & $9,8 \%$ & $7,8 \%$ & $0,0 \%$ \\
\hline Természeti erőforrások & $7,9 \%$ & $3,7 \%$ & $10,9 \%$ & $0,0 \%$ \\
\hline Környezetvédelem és klimaváltozás & $6,3 \%$ & $9,1 \%$ & $5,4 \%$ & $0,0 \%$ \\
\hline Információ- és kommunikáció technológia & $4,8 \%$ & $6,1 \%$ & $4,5 \%$ & $0,0 \%$ \\
\hline Mezögazdaság & $2,6 \%$ & $2,7 \%$ & $2,7 \%$ & $0,0 \%$ \\
\hline Kutatás-fejlesztés & $2,1 \%$ & $3,0 \%$ & $1,8 \%$ & $0,0 \%$ \\
\hline Ingatlan-beruházások & $2,0 \%$ & $2,4 \%$ & $2,0 \%$ & $0,0 \%$ \\
\hline Vállalkozások és kockázati tőke & $1,9 \%$ & $5,1 \%$ & $0,4 \%$ & $0,0 \%$ \\
\hline Infrastruktúra fejlesztések & $1,6 \%$ & $1,7 \%$ & $1,6 \%$ & $0,0 \%$ \\
\hline Müszaki beruházások & $1,2 \%$ & $2,7 \%$ & $0,5 \%$ & $0,0 \%$ \\
\hline Gyógyszeripar & $1,0 \%$ & $1,7 \%$ & $0,7 \%$ & $0,0 \%$ \\
\hline Innováció & $1,1 \%$ & $2,7 \%$ & $0,4 \%$ & $0,0 \%$ \\
\hline M\&A ügyletek & $0,4 \%$ & $0,0 \%$ & $0,7 \%$ & $0,0 \%$ \\
\hline Egyéb & $1,9 \%$ & $3,7 \%$ & $1,1 \%$ & $0,0 \%$ \\
\hline
\end{tabular}

Forrás: saját szerkesztés a Google Scholar 2011-2016-os időszak közötti „real options” keresőszóra kiadott eredménylistája alapján (angol nyelvű tanulmányokra, gazdálkodástanhoz köthető eredményekre szürés után 951 tanulmány absztrakt és kulcsszó elemzése) 
szemléletü, a szervezeti karakterisztikák és viselkedési aspektusok figyelembevételére koncentráló eredményeknek, ajánlásoknak kell a gyakorlat szolgálatába állniuk.

A második dimenzió, mellyel az irodalomkutatás során foglalkoztam, az alkalmazási terület volt. Jól látszik a 6 . táblázat soraiban, hogy az alkalmazási területek számossága meghaladja a 16-ot, úgy, hogy az egyéb kategóriába soroltam minden, ötnél kevesebb tanulmányban megjelenő iparágat, területet (ezekröl késöbb bövebben). A 6 . táblázat relevancia szerinti csökkenő sorrendben sorolja az alkalmazási területeket. A tanulmányok 42,3\%-a általánosságban foglalkozik a reálopció-elmélettel, legyen szó annak kvalitatív, kvantitatív vagy stratégiai adaptációjáról. Utóbbi esetben a fellelhető tanulmányok mindegyike ide sorolható. Ezt követően a sorban a jelentős tőkeráfordítással járó, jellemzően irreverzibilis projektekkel jellemezhető iparágak (villamosenergia-szektor, természeti erőforrások, információ- és kommunikációtechnológia stb.) projektjei sorolhatóak. Érdekes eredmény, hogy a termelésmenedzsment témaköréhez kapcsolódó (elsősorban az ellátási lánc értékelésére, kvalitatív elemzésére, optimalizálására, tervezési rendszerek vizsgálatára fókuszáló) tanulmányok a harmadik leggyakrabban előforduló alkalmazási területe a reálopcióknak. A klímaváltozás, környezetvédelem, vállalatok társadalmi felelősségvállalásának elemzésével foglalkozó, elsősorban kvalitatív munkák szintén előkelö helyen sorolódnak.

Amennyiben a két dimenzió belső elemzésébe kezdünk, jól látszik, hogy a villamosenergia-szektorhoz kötődő tanulmányok a kvantitatív elemzések több mint 20\%-át teszik ki, ezzel a reálopció-elemzés módszertani fejlesztésére irányuló általános alkalmazás mögött egyértelmủen a kategórián belüli domináns munkák. Ugyanezt a belső szerkezetet vizsgálva a kvalitatív, reálopciós logikai munkákon belül, jóval elaprózódottabb a kép. A rugalmasság kvalitatív megragadására a termelésmenedzsment, a környezetvédelem, valamint a villamosenergia-szektor szolgáltatja a legjobb alapot. Az egyéb kategóriában olyan alkalmazásokat találunk, melyek kötődnek a sport, a divat, az ürkutatás, a közszolgáltatások és szabályalkotási területekhez.

Ezek az eredmények egyértelmüen alátámasztják a reálopció-elmélettel szemben elsősorban a gyakorlati szakemberek oldaláról megfogalmazódott kritikát. Nem létezik egy általánosan elfogadott, generalista reálopciós modell, mely minden esetben bevethető lenne, sokkal inkább jellemző a case-by-case, eseti jellegű bevetése a reálopciós logikának, eszköztárnak. Ugyanakkor fontos megjegyeznem, hogy véleményem szerint a kutatási eredmények, az elméleti adaptáció oldalán egyfajta kettősség figyelhető meg. Egyrészt az általános alkalmazásoknak (az összes tanulmány 42,3\%-a) csaknem 7\%-a a reálopció-elmélet kritikai elemzése, a fennmaradó tanulmányok pedig a modellpontosítást, illetve a kvalitatív flexibilitás értelmezést helyezik fókuszukba, vagyis jellemzően már a kritikai elemzések által megfogalmazott igényekre reagálnak. Ugyanakkor az alkalmazási területek számossága alapján a kutatók egy olyan módszertant, logikai keretrendszert látnak a reálopciókban, mely csaknem minden területen bevethetö.

\section{Összegzés}

A reálopció-elmélet központi premisszája szerint a menedzseri döntések fókuszában a flexibilitást növelő, a bizonytalanságot csökkentő opciók felismerése, létrehozatala, majd ezek lehívása (érvényesítése), vagy le nem hívása (nem érvényesítése) áll. Amennyiben képesek vagyunk - e kettős törekvésünk szem előtt tartásával - reálopciókat felismerni, létrehozni, illetve alkalmazni, nem egyszerüen a kockázatokkal szembeni ellenálló-képességünk javulása valósulhat meg, de hosszú távon a részvényesi érték növekedése egyaránt. A reálopciók potenciálisan egy jóval hatékonyabb módot kínálnak a vezetőknek a cégük tőkéjének allokálására, és a részvényesek vagyonának maximalizálására a bizonytalanság kezelésével és a kockázat csökkentésével. Bár a reálopció-elmélet nem vált a beruházáselmélet általánosan elfogadott paradigmájává, a nagy horderejü, stratégiai jelentőségü kérdések döntéshozói számára létfontosságú a reálopciók által nyújtott elönyök figyelembevétele.

Jelen tanulmány a reálopció kifejezés első említése óta eltelt 40 év reálopciós kutatási irányainak, eredményeinek sajátos szintetizálásra tett kísérletet, mely szintetizálás célja a meglévő alkalmazásra jellemző sokszínüség keretek közé szorítása, a gyakorlati szakemberek megértésének szolgálata, valamint a kutatási rések azonosítása volt. A felépített stratégiai keretrendszer ismertetése során megfogalmazott következtetések empirikus alátámasztása érdekében egy irodalomkutatást végeztem, melynek eredményeként kristályozódtak a reálopció-elmélet előtt álló kutatási feladatok és gyakorlati implikációk. A szervezetbe ágyazott, stratégiai alkalmazások előtérbe kerülését, a reálopciók portfólió szemléletű elemzésének térnyerését, valamint a generalista modellalkotás irányába mutató kutatási fókusz elmélyülését várhatjuk az elmélet következő évtizedétől.

\section{Jegyzet}

${ }^{1}$ Az időszak kiválasztása mögött a minimum 1000 tanulmányalapú minta elérésének igénye áll.

\section{Felhasznált irodalom}

Adner, R.-Levinthal,D.(2002): TheEmergenceofEmerging Technologies. California Management Review, 45(1), p. 50-66.

Anderson, T. (2000): Real Options Analysis in Strategic Decision Making: An Applied Approach in a Dual Options Framework. Journal of Applied Management Studies, Vol. 9, No. 2 (2000), p. 235-255.

Amram, N. - Kulatilaka, N. (1999): Real Options: Managing Strategic Investment in an Uncertain World. Boston: Harvard Business School Press

Amram, M. - Howe, K. (2002): Capturing the Value of Flexibility. Strategic Finance, Vol. 84, No. 6 (2002), p. 10-13.

Arnold, T. - Shockley, R. (2001): Value Creation at Anheuser-Busch: A Real Options Example. Journal of Applied Corporate Finance, Vol. 14, No. 2 (2001), p. 52-61. 
Billington, C. - Kuper, A. (2000): Supply Chain Strategy: Real Options for Doing Business at Internet Speed. Ascett, Vol 2, April, 2000

Baghai, M. - Coley, S. - White, D. (1999): The Alchemy of Growth. Boulder: Perseus

Banyár J. - Bozsik S. - Csapi V. - Fazakas G. - Gyulai L.- Kürthy G. - Solt K. (2010): Pénzügyi ismeretek. Budapest: Magyar Könyvvizsgálói Kamara Oktatási Központ Kft.

Bélyácz I. (2010): Kockázat vagy bizonytalanság? Elmélettörténeti töredék a régi dilemmáról. Közgazdasági Szemle, július-augusztus, p. 573-590.

Benaroch, M. (2002): Managing Information Technology Investment Risk: A Real Options Perspective. Journal of Management Information Systems, 19 (2), p. 43-84.

Blyth, W. - Bradley, R. - Bunn, D. - Clarke, C. - Wilson, T. - Yang, M. (2007): Investment Risks under Uncertainty. Energy Policy, 35, p. 5766-5773.

Bockemühl, M. (2001): Realoptionstheorie und die Bewertung von Produktinnovationen: Der Einfluss Von Wettbewerbseffekten. Wiesbaden

Broyles, J. (2003): Financial Management and Real Options. Chichester: Wiley

Brennan, M. - Schwartz, E. (1977): The Valuation of American Put Options. Journal of Finance, Vol. 32, p. 449-462.

Brach, M. (2003): Real Options in Practice. Hoboken: Wiley

Chi, T. (2000): Option to acquire or divest a joint-venture. Strategic Management Journal, 21, p. 665-687.

Courtney, H. - Kirkland, J. - Viguerie, P. (2001): Strategy under Uncertainty. McKinsey-Quarterly, December 2001, p. $5-14$.

Copeland, T. E. - Antikarov, V. (2003): Real Options: A Practitioner's Guide. New York: Texere

Copeland, T. E. - Howe, K. (2002): Real Options and Strategic Decisions. Strategic Finance, Vol. 83, No. 10 (2002), p. 8-11.

Copeland, T. E. - Keenan, P. T. (1998): How Much is Flexibility Worth? McKinsey Quarterly, Nr. 2, p. 38-49.

Copeland, T. E. - Koller, T. - Murrin, J. (2000): Valuation: Measuring and Managing The Value of Companies. New York: Wiley

Cyert, R. M. - March, J. G. (1963): A Behavioral Theory of the Firm. Englewoods Cliffs, NJ: Prentice-Hall

De Neufville, R. (2002): Class Notes for Engineering Systems Analysis for Design. Cambridge: MIT Engineering School-Wide Elective

De Weck, O. (2004): Staged Deployment of Communications Satellite Constellations in Low Earth Orbit. Journal of Aerospace Computing, Information, And Communication, March, p. 119-136.

Dias, M. A. G. (2006): Real Options theory for Real Asset portfolios: The oil exploration case. http://www.pucrio.br/marco.ind/pdf/dias_portfolio_ep.pdf Letöltve: 2017. 01.12.

Dixit, A. K. - Pindyck, R. S. (1994): Investment under Uncertainty. Princeton: Princeton University Press
Dosi, G. (1982): TechnologicalParadigmsand Technological Trajectories: A Suggested Interpretation of the Determinants and Directions of Technical Change. Research Policy, 11, p. 147-162.

Dörner, W.(2003): It-Investitionen:Investitionstheoretische Behandlung von Unsicherheit. Hamburg: Verlag Dr. Kovac

Franke, G. - Hax, H. (1999): Finanzwirtschaft des Unternehmens und Kapitalmarkt. Berlin: Springer

Hartmann, M. (2006): Realoptionen als Bewertungsinstrument für Frühe Phasen der Forschung und Entwicklung in der Pharmazeutischen Industrie. Genehmigte Dissertation. Berlin: Technische Universität Berlin

Hommel, U. (2000): Der Realoptionsansatz Wird Bald Standard Sein. Frankfurter Allgemeine Zeitung, 8.5. 2000

Hommel, U. - Lehmann, H. (2001): Die Bewertung von Investitionsobjekten mit dem Realoptionsansatz Ein Methodenüberblick. In: Hommel, U./Vollrath, R./Scholich, M. (Hrsg.): Realoptionen In Der Unternehmenspraxis. Berlin: Springer, p. 113-129.

Hommel, U. - Pritsch, G. (1999): Marktorientierte Investitionsbewertung mit dem Realoptionsansatz. Finanzmarkt und Portfoliomanagement, 13/2., p. 121144.

Hubbard, G. R. (1994): Investments Under Uncertainty: Keeping One's Options Open. Journal of Economic Literature, 32 (4), p. 1816-1831.

Hungenberg, H. (2001): Strategisches Management in Unternehmen: Ziele - Prozesse - Verfahren. Wiesbaden: Springer

Hutzschenreuter, T. (2001): Wachstumsstrategien: Einsatz von Managementkapazitäten zur Wertsteigerung. Wiesbaden: Springer

Kensinger, J. (1987): Adding the Value of Active Management into the Capital Budgeting Equation. Midland Corporate Finance Journal, Vol. 5, No. 1 (Spring), p. 31-42.

Kester, W. (1984): Today's Options for Tomorrow's Growth. Harvard Business Review, Vol. 62, No. 2 (1984), p. 153-160.

Leslie, K. J. - Michaels, M. P. (1997): The Real Power of Real Options. The McKinsey Quarterly, No. 3, p. 4-22.

Luehrman, T. A. (1998): Strategy as a Portfolio of Real Options. Harvard Business Review, SeptemberOctober, p. 89-99.

Margrabe, $W$. (1978): The Value of an Option to Exchange One Asset for Another. Journal of Finance, Vol. 33, No. 1, p. 177-186.

Mcdonald, R. - Siegel, D. (1985): Investment and the Valuation of Firms When There is an Option to Shut Down. International Economic Review, No.26, June, p. 331-349.

Mcgrath, R. - Macmillan, I. (2000): Assessing Technology Projects Using Real Options Reasoning. Research and Technology Management, Vol. 43, No. 4 (2000), p. 35-49. 
Mcgrath, R. (1997): A Real Options Logic for Initiating Technology Positioning Investments. Academic Management Review, Vol. 22, No. 4 (1997), p. 974996.

Myers, S. C. (1977): Determinants of Corporate Borrowing. Journal of Financial Economics, 5(2), p. 147-176.

Myers, S. C. - Majd, S. (1990): Abandonment Value and Project Life. Advances in Futures and Options Research, Vol. 4, p. 1-21.

Nelson, R. R. - Winter, S. G. (1982): An Evolutionary Theory of Economic Change. Cambridge: Belknap Press/Harvard University Press

Penrose, E. T. (1959/1995): The Theory of the Growth of The Firm. Oxford: Oxford University Press

Pindyck, R. (2000): Irreversibilities and the Timing of Environmental Policy. Resource and Energy Economics, 22(3), p. 233-259.

Pritsch, G. (2000): Realoptionen als ControllingInstrument. Wiesbaden: Springer

Pritsch, G. - Weber, J. (2003): Die Bedeutung des Realoptionsansatzes aus Controlling-Sicht, In: U. Hommel - M. Scholich (hrsg.) (2003): Reale Optionen: Konzepte, Praxis und Perspektiven Strategischer Unternehmensfinanzierung. Berlin: P. Baecker, p. 143172.

Porter, M. (2000): Wettbewerbsvorteile: Spitzenleistungen Erreichen und Behaupten. Frankfurt Am Main/New York 2000.

Richmond, W. B. - Seidmann, A. (1993): Software Development Outsourcing Contract Structure and Business Value. Journal of Management Information Systems, Vol. 10 No. 1, p. 57-72.

Risak, J. - Grün, O. (1985): Der Weg Aufwärts! Abschaffen. Die Betriebswirtschaft, 45, 1985, s. 646-658.

Robichek, A. A. - Van Horne (1967): Abandonment Value and Capital Budgeting. Journal of Finance, December 1967, p. 577-590.
Rózsa A. (2008): Képességek vagy reálopciók? A stratégiai és pénzügyi szempontok egyeztetésének lehetőségei és korlátai különös tekintettel a rugalmas technológiai beruházások problémáira. Doktori értekezés. Pécs: Pécsi Tudományegyetem Közgazdaságtudományi Kar, Gazdálkodástani Doktori Iskola

Rózsa A. (2007): A reálopciók lehetőségei és korlátai a stratégiai beruházások értékelésében. Budapest: Budapesti Gazdasági Főiskola Külk. Kar. http://elib. kkf.hu/okt_publ/szf_19_06.pdf Letöltve: 2017.01.14.

Schulmerich, M. (2010): Real Options Valuation the Importance of Interest Rate Modelling in Theory and Practice. Berlin; Heidelberg: Springer-Verlag

Smit, H.T.J. - Trigeorgis L. (2007): Strategic options and games in analyzing dynamic technology investments. Long Range Planning, 40, p. 84-114.

Triantis, A. - Borison, A. (2001): Real Options: State of the Practice. Journal of Applied Corporate Finance, 14 (No. 2), p. 8-24.

Trigeorgis, L. (1996): Real Options: Managerial Flexibility and Strategy in Resource Allocation. Boston, MA.: MIT Press

Trigeorgis, L. (1997): Real Option, Managerial Flexibility and Strategy in Resource Allocation. Boston MA.: The Mit Press

Trigeorgis, L. - Mason, S. P. (1987): Valuing Managerial Flexibility. Midland Corporate Finance Journal, Vol. 5, No. 1, Spring, p. $14-21$.

Trigeorgis, L. - Reuer, J. J. (2017): Real options theory in strategic management. Strategic Management Journal, 38, p. 42-63.

Witt, J. - Kaltschmitt, M. (2003): Weltweite Nutzung Regenerativer Energien. Bwk, 55, p. 64-71.

Wang, T. - De Neufville, R. (2004): Building Real Options into Physical Systems with Stochastic Mixed-Integer Programming. 8th Annual Real Options International Conference, Montreal, Canada 